\title{
Uji Aktivitas Antibakteri dari Ekstrak Rumput Mutiara (Hedyotis corymbosa (L.) Lamk)
}

\author{
Lela Mukmilah $\mathbf{Y}^{1}$, Zalinar Udin ${ }^{2}$, Elis Lisnawati ${ }^{1}$ \\ ${ }^{1}$ Program Studi Kimia Universitas Muhammadiyah Sukabumi \\ ${ }^{2}$ Lembaga Ilmu Pengetahuan Indonesia (LIPI) Bandung \\ e-mail: lelathea@yahoo.co.id
}

\begin{abstract}
Abstrak
Rumput mutiara merupakan tanaman yang berguna sebagai obat tradisional, tanaman ini termasuk kedalam famili tumbuhan Rubiaceae. digunakan sebagai obat alternatif penyebab penyakit infeksi yang disebabkan karena masuknya mikroorganisme kedalam tubuh. Salah satu mikroorganisme yang mengakibatkan penyakit ini adalah bakteri ( Amonim, 1993). Antibakteri adalah senyawa kimia yang dapat membunuh atau memghambat pertumbuhan mikroorganisme penyebab penyakit dengan kerusakan minimal jaringan induknya. Dilakukan penelitian aktivitas antibakteri dari ekstrak rumput mutiara (Hedyotis corimbosa (L.) Lamk) terhadap pertumbuhan beberapa bakteri, yang dlilakukan melalui 4 tahapan yaitu tahapan maserasi, tahapan ekstraksi fraksinasi, tahap pengujian fitokimia, dan diteruskan dengan tahap pengujian aktivitas antibakteri menggunakan metode difusi agar, parameter yang digunakan adalah dengan melihat zona terang yang dihasilkan (zona yang tidak terjadi pertumbuhan). Hasil penelitian menunjukkan bahwa dalam ekstrak rumput mutiara terdapat zat aktif yang berfungsi sebagai antibakteri yang terdapat dalam fraksi metilen klorida, pada fraksi ini aktivitas paling baik dihasilkan oleh bakteri S. Disentry dengan diameter daerah hambatan sebesar $27,5 \mathrm{~mm}$.
\end{abstract}

Kata kunci : Antibakteri, Rumput mutiara sebagai tanaman obat.

\begin{abstract}
Rumput mutiara is a useful plant as a traditional medicine, this plant is included into the Rubiaceae plant families, used as an alternative medicine that caused by the entery of mikroorganisns into the body. One of the microorganisms the couse disease are bactera (Aminim, !993). Antibakterial is chemical compound that can kill or inhibit the growth of disease causing microorganisms with minimal damage to your hame network. Conducted research antibakterial activity of the extract on the growth of rumput mutiara (Hedyotis corymbosa (L.) Lamk) same bacteria. Conductedtrongh 4 stages of maceration stages, fractionation extraction stage, the stage at the ftytochemical and activity continue antibacterial hase diffusion methed $\ln$ order, the parameters used are seeling the light zone (zone growth the does not happen). The results shawed that there is a rumput mutiara extract on a substance whict actif as an antibacterial fraction terapat in metilen choride. The fraction is the best activity prodec by bacterium $S$. Disentry whit a diameter of $27,5 \mathrm{~mm}$.
\end{abstract}

Keywords : Antibacterial, rumput mutiara as a medicinal plant. 


\section{PENDAhULUAN}

Indonesia merupakan salah satu negara yang kaya akan sumber daya alam terutama tumbuh-tumbuhan yang banyak tersebar diseluruh kepulauan Indonesia. Sejak zaman dahulu, masyarakat kita sudah memanfaatkan tumbuh-tumbuhan berkhasiat obat untuk pengobatan tradisional. Pengobatan tradisional pada umumnya adalah pengobatan dengan menggunakan ramuan dari tumbuhan yang berkhasiat atau diperkirakan berkhasiat sebagai obat (Amonim,1993).

Ekstraksi pelarut atau sering disebut dengan ekstraksi cair merupakan metode pemisahan atau pengambilan zat terlarut dalam larutan dengan menggunakan pelarut lain biasanya menggunakan pelarut organik, ekstraksi pelarut merupakan metode yang paling baik dan popular, karena metode ini dapat dilakukan baik dalam tingkat makro maupun mikro, tidak memerlukan alat canggih atau khusus, bersifat sederhana, cepat, mudah, serta tidak memerlukan waktu lama (Yazid, 2005). Menurut jawetz et al (2001) berdasarkan mekanisme kerja antimikroba secara umum dapat dikelompokan kedalam 4 kelompok utama yaitu antibakteri yang menghambat sintesis dinding sel bakteri, antibakteri yang menghambat fungsi membran dinding sel bakteri, antibakteri yang menghambat sintesis protein sel bakteri, antibakteri yang menghambat sintesis asam nukleat.

Rumput mutiara (Hedyotis Corymbosa (L.) lamk, merupakan salah satu tumbuhan yang menarik perhatian yang dapat dijadikan sebagai obat tradisional, karena dalam rumput mutira terdapat salah satu zat aktif yang bersifat antioksidan selain itu tanaman ini mudah didapat karena tumbuh subur di tanah lembab. Tamanan ini termasuk ke dalam famili tumbuhan Rubiaceae dikenal dengan nama daerah rumput siku-siku, daun mutiara atau katepan. Digunakan sebagai obat kanker, hepatitis, usus buntu, tulang patah, dan merupakan salah satu upaya untuk pengobatan tradisional yang dapat digunakan sebagai alternatif pengobatan penyakit infeksi, untuk itu diperlukan penelitian lebih lanjut menggenai aktifitas antibaketri Rumput mutiara (Hedyotis corymbosa (L.) Lamk (Amonim, 1993).Apakah Ekstrak rumput mutiara (Hedyotis corymbosa (L.) Lamk. mempunyai aktifitas antibakteri? jenis bakteri mana yang paling baik aktivitasnya terhadap ekstrak rumput mutiara.

Hasil penelitian ini diharapkan dapat memberikan kontribusi berupa informasi tentang daya antibakteri sehingga dapat dimanfaatkan sebagai pertimbangan terhadap penelitian lain yang berkaitan dengan tumbuhan tradisional atau sebagai strategi dalam pengembangan obat tradisonal.

\section{METODE PENELITIAN}

\section{Bahan dan Alat}

Bahan yang digunakan adalah rumput mutiara (Hedyotis corymbosa (L.) Lamk), pelarut teknis yang didisitilasi ulang yaitu: methanol, N- heksan, metilen klorida, etil asetat, dan butanol, asam asetat anhidrid, amil alkohol, $\mathrm{H}_{2} \mathrm{SO}_{4}, \mathrm{NaOH}, \mathrm{NH}_{4} \mathrm{OH}$, pereaksi dragendorf (larutan $\mathrm{KI}$ dan $\mathrm{HCl}$ dalam air), pereaksi fosfomolibdat (larutan $\mathrm{KI}$ dan $\mathrm{HCl}$ dalam etanol $5 \%$ ) besi (III) klorida, serbuk Mg, Gelatin1\%, viniliin, larutan $\mathrm{HCl} 0,1 \mathrm{~N}, \mathrm{HCl} 1 \mathrm{~N}$, dan dimetil sufoksida (DMSO)

Media yang digunakan untuk pembiakan adalah nutrient agar (Bakto Nutrien agar), dengan formula perliter adalah beef extract 5 gram, bacto pepton 5 gram, bakto agar sebanyak 15 gram. Bakteri yang digunakan dalam pengujian aktifitas antibakteri adalah Bacilus subttilis, Stophylococcus aureus, E. Coli, P. Auroginos, S. Disentry, S. Parathypi. Zat perbandingan rumput mutiara dalam pengujian aktifitas antibakteri dibandingkan dengan tetrasiklin kristal.

Alat yang digunakan dalam penelitian adalah perkulator, corong pemisah, corong, kertas saring, spatula, gelas kimia, erlemeyer $500 \mathrm{~mL}$, cawan petri, labu penguap, botol kecil, pipet tetes, gelas ukur $100 \mathrm{~mL}$, balp, alat pengisap gasing vakum, pinset, oven, tisu, kapas, kain kasa, neraca analitik, pipet mikro, autoklaf, pencungkil, stirer magnet, kawat platina, tabung reaksi, lampu pijar.

\section{Prosedur Penelitian}

1. Tahap Maserasi

Sediakan daun rumput mutiara sebanyak $1 \mathrm{~kg}$ kemudian keringkan dan hancurkan sampai ukuran kecil-kecil, setelah benar-benar kering 
baru masukkan kedalam kolom yang besar dan direndam dengan menggunakn pelarut etanol selama satu minggu, setelah direndam selama satu minggu kemudian pelarut rendaman dikeluarkan lalu diuapkan dengan evaporator putar pada suhu $40^{\circ} \mathrm{C}$ dan menghasilkan ekstrak pekat etanol, proses perendaman dilakukan sebanyak $3 \mathrm{x}$.

2. Tahap Ekstraksi Fraksinasi Larutan Uji

Ekstrak pekat yang didapat ditimbang sebanyak 50 gram, kemudian dilarutkan dengan metanol : air ( 4:1), diaduk-aduk sampai larut, lalu disaring sehingga menghasilkan filtrat dan residu, untuk residu dikeringkan dan ditimbang, sedangkan untuk ekstrak metanol : air dilakukan ekstrasi partisi dengan berbagai pelarut. Ekstraksi awal ekstrak metanol : air di ektraksi dengan n-heksana sebanyak $250 \mathrm{~mL}$, dikocok sampai terjadi pemisahan kemudian dipisahkan dan di evaporasi sampai menghasilkan fraksi nheksana, residu yang tidak larut dalam n-heksana diektraksi dengan pelarut metilen klorida $\left(\mathrm{CH}_{2} \mathrm{Cl}_{2}\right)$, sampai menghasilkan fraksi metilen klorida, residu yang diperoleh selanjutnya diekstraksi dengan etil asetat kemudian dengan butanol, residu yang tidak larut dengan butanol dinyatakan sebagai residu akhir. Kelima fraksi yang diperoleh di uji fitokimia dan uji aktivitas antibakterinya.

\section{Pengujian Fitokimia}

1. Identifikasi Golongan Senyawa Alkaloid ( Harborne, 1987)

Larutan uji hasil ekstraksi dibasakan dengan larutan amonia $10 \%$, larutan basa di ekstraksi dengan kloroform, ekstrak kloroform diasamkan dengan $\mathrm{HCl} 1 \mathrm{~N}$, kemudian asam dipisahkan dan uji dengan pereaksi dragendorf, endapan putih atau kuning menyatakan adanyanya alkaloid.

2. Identifikasi Golongan Senyawa Fenol

(Harborne, 1987)

Larutan uji hasil ekstraksi dimasukan dalam tabung reaksi, selanjutnya ditambahkn pereaksi $\mathrm{FeCl}_{3}$ dalam larutan etanol, hasil positif ditunjukkan dengan adanya warna hijau, merah unggu, biru dan hitam.

3. Identifikasi Senyawa Flavonoid

(Harborne, 1987)

Larutan uji hasil ekstraksi dimasukkan ke dalam tabung reaksi yang berisi butiran logam $\mathrm{Mg}$ dan larutan $\mathrm{HCl} 2 \mathrm{~N}$, campuran ini dipanaskan selama

5-10 menit, setelah dingin dan di saring, kedalam filtrat ditambahkan amil alkohol di kocok kuat-kuat, warna merah atau jingga pada lapisan amil alkohol menunjukkan adanya flavonoid.

4. Identifikasi Senyawa Triterpenoid dan Steroid (Harborne, 1987)

Identifikasi senyawa triterpenoid dan steroid dilakukan dengan pereaksi Lieberman burchard, larutan uji hasil ekstraksi ditambahkan asam asetat anhidrat sampai zat terendam, dibiarkan selama 15 menit, Selanjutnya ditambahkan 1 tetes larutan $\mathrm{H}_{2} \mathrm{SO}_{4}$ pekat, perubahan warna yang terjadi diamati, apabila terbentuk warna hijau biru maka menunjukkan hasil positif untuk steroid, sedangkan untuk triterpenoid ditandai dengan adanya warna ungu.

5. Identifikasi Golongan Senyawa Saponin (Harborne, 1987)

Larutan uji hasil ekstraksi dididihkan dalam penangas air selama 5 menit, setelah dingin kemudian disaring, filtrat dikocok kuatkuat dengan arah vertikal selama 1-2 menit, senyawa saponin dapat ditunjukkan dengan adanya busa setinggi $1 \mathrm{~cm}$ yang stabil setelah dibiarkan selama 1 jam atau pada penambahan 1 tetes $\mathrm{HCl} 0,1 \mathrm{~N}$.

6. Identifikasi Senyawa Tanin (Trevor, 1995)

Larutan uji hasil ekstraksi ditambahkan larutan gelatin $1 \%$ kedalam tabung reaksi, hasil positif ditandai dengan adanya endapan putih.

7. Identifikasi Gologan Senyawa Terpenoid (Harborne, 1987)

Larutan uji hasil ekstraksi diletakkan pada plat tetes, kemudian ditambahkan vanillin dan $\mathrm{H}_{2} \mathrm{SO}_{4}$ pekat, Perubahan warna yang terjadi diamati.

\section{Pengujian Aktivitas Antibakteri}

Pengujian aktivitas antibakteri dilakukan dengan tahapan sebagai berikut :

1. Penyediaan Media (Irianto.K, 2006)

Nutrien agar yang telah ditimbang sebanyak 4,6 gram dilarutkan dalam $200 \mathrm{ml}$ aquades, dihomogenkan dengan bantuan pemanasan dan stirer magnet sampai mendidih dan berwarna bening. Kemudian dimasukan kedalam tabung reaksi yang tiap-tiap tabung berisi $5 \mathrm{~mL}$ lalu tutup dengan kasa dan kapas. 
Sebelum digunakan disteril dalam autoklof $121^{\circ} \mathrm{C}$ selam 20 menit.

2. Penyedian Bakteri Uji (Irianto.K, 2006)

Bakeri yang akan diuji (E.coli, P.auroginosa, S.parathypii, S.disentry, S.aureus, dan S.subtilis), ditanam diatas media agar miring dari nutrien agar yang telah disterilkan, dengan cara penggesekan, lalu diinkubasi pada suhu $37^{\circ} \mathrm{C}$ selama 18 jam. Setelah diinkubasi bakteri yang akan diuji di pindahkan kedalam tabung reaksi yang berisi aquades yang telah disteril, tabung diputar diantara dua telapak tangan sehingga diperoleh suatu suspensi bakeri, suspensi diencerkan dengan aquades steril sehingga optiknya (OD: Optical Density) pada panjang gelombang $600 \mathrm{~nm}$ adalah 0,6 dengan blangko air aquades.

3. Cara Pengujian Aktivitas Antibakeri (Irianto.K, 2006)

Suspensi bakteri sebanyak $100 \mu \mathrm{L}$ dimasukan kedalam cawan petri steril, ditambahkan nutrien agar steril sebanyak 15 $\mathrm{mL}$, cawan petri digoyang supaya isinya homogen, dan biarkan beberapa saat sampai agar membeku pada suhu kamar. Pada media yang telah memadat dibuat sumur dengan diameter 6 $\mathrm{nm}$, masing-masing lubang diisi dengan $20 \mu \mathrm{L}$ larutan sampel (ekstrak etanol, fraksi MTC, fraksi heksan, fraksi etil asetat, fraksi butanol dan residu), dan diinkubasikan pada suhu $37^{\circ} \mathrm{C}$ selama 18 jam kemudian ukur diameter hambatan yaitu diameter daerah bening lubang. Cara yang sama dilakukan untuk penguji aktivitas antibakeri pada larutan standar antibakteri.

4. Uji MIC (Minimum Inhibitory Concentration) Cara Padat (Irianto, K.2006)

Setelah diketahui fraksi yang paling aktif kemudian diuji MIC yaitu dengan cara memasukkan $1 \mathrm{~mL} \quad(1000 \mu \mathrm{L})$ berbagai konsentrasi sampel fraksi aktif kedalam cawan petri, kemudian ditambahkan $9 \mathrm{~mL}$ nutrien agar, cawan digoyang-goyang supaya isinya bercampur homogen dan biarkan beberapa saat sampai larutan beku pada suhu kamar, inokulasi bakteri yang akan digunakan pada media yang telah membeku dengan cara menggoreskannya kemudian diinkubasi selama 18 jam pada suhu $37^{\circ} \mathrm{C}$, hambatan minimum dapat dillihat dengan adanya pertumbuhan bakeri pada permukaan media.

\section{HASIL DAN PEMBAHASAN}

\section{Ekstraksi Fraksinasi}

Dari ekstrak pekat etanol hasil maserasi $1 \mathrm{~kg}$ daun rumput mutiara diambil sebanyak 50 gram, yang kemudian diekstraksi partisi dengan menggunakan beberapa pelarut yaitu pelarut nheksan, metilen klorida, etil asetat dan butanol diperoleh hasil seperti yang terlihat pada tabel 1 :

Tabel 1. Hasil Rendemen Ekstrak dan fraksinasi hasil pemisahan

\begin{tabular}{|c|l|c|}
\hline No & \multicolumn{1}{|c|}{ Ekstrak } & \% Rendemen \\
\hline 1 & Fraksi N-Heksan & 0,29752 \\
\hline 2 & Fraksi MTC & 0.47816 \\
\hline 3 & Fraksi Etil Asetat & 0.10567 \\
\hline 4 & Fraksi Butanol & 0.20154 \\
\hline
\end{tabular}

Tahap perendaman pertama dilakukan selama 3 hari, ini dilakukan supaya senyawa yang berada dalam tumbuhan akan larut dengan maksimal dalam pelarut, perendaman ini dilakukan 3 kali sampai pelarut itu tidak berwarna lagi. Hasil maserasi dari daun rumput mutiara kering sebanyak $1 \mathrm{~kg}$ menghasilkan ekstrak pekat sebanyak 101,4 gram, berarti senyawa yang larut dalam etanol hanya sekitar $10,14 \%$.

Tahap ekstraksi dilakukan dengan 5 pelarut untuk memisahkan senyawa kimia yang larut berdasarkan tingkat kepolarannya (Andrea Yan, 2000). Berdasarkan data hasil fraksinasi dapat menunjukkan bahwa fraksi terbanyak terkumpul pada fraksi semi polar yaitu pada fraksi metilen klorida dengan hasil rendemen mencapai $0.47816 \%$ dibandingkan dengan pelarut semi polar lain yang hanya mencapai $0.10567 \%$ pada pelarut etil asetat, ini karena golongan senyawa yang terkandung dalam rumput mutiara kebanyakan mempunyai karakteristik yang hampir sama dengan pelarut metilen klorida sehingga senyawa tersebut cenderung larut pada metilen klorida. Selain itu juga dalam rumput mutiara mengandung senyawa-senyawa yang bersifat polar dan non polar hanya saja kandungannya kecil yaitu $0.2975 \%$ pada pelarut n-heksan (non polar), dan 
$0.20154 \%$ pada pelarut butanol (polar). Ini menujukkan bahwa senyawa yang terkandung dalam rumput mutiara cenderung lebih larut pada pelarut semi polar dibanding dengan pelarut non polar dan polar karena diduga dalam rumput mutiara lebih banyak mengandung golongan senyawa kimia yang bersifat semi polar akan tetapi sifat-sifat dan jenis golongan tersebut belum diketahui.

\section{Pengujian Fitokimia}

Berdasarkan hasil pengujian fitokimia terhadap ekstrak pekat etanol, fraksi n-heksan, fraksi metilen klorida, fraksi etil asetat, fraksi butanol dan residu tumbuhan rumbut mutiara, menunjukkan beberapa golongan senyawa yang terdeteksi seperti terlihat pada tabel 2.

Hasil pengujian fitokimia yang dilakukan pada ekstrak pekat etanol, fraksi n-hekasa, fraksi metilen klorida, fraksi etil asetat, fraksi butanol dan residu tumbuhan rumput mutiara menunjukkan beberapa golongan senyawa yang terdeteksi yaitu : tanin, fenol, terpenoid, saponin, flavonoid dan steroid dalam ektrak pekat (ekstrak etanol) dan etil asetat, dalam fraksi butanol, fraksi heksan dan residu terdeteksi adanya senyawa golongan tanin, fenol, terpenoid dan steroid, sedangkan dalam fraksi metilen klorida terdeteksi adanya senyawa golongan tanin, fenol, terpenoid, flavonoid dan steroid. yang tidak terdeteksi senyawa alkaloid dan triterpenoid ini menunjukan bahwa senyawa alkaloid dan triterpenoid tidak terdapat dalam tumbuhan rumput mutiara.

\section{Pengujian aktivitas antibakteri}

Pengujian aktivitas antibakteri dilakukan sterilisasi terhadap media dan peralatan yang digunakan. Metode yang lazim digunakan untuk mensterilkan ditempatkan dalam autoklaf pada tekanan $15 \mathrm{lb} / \mathrm{in}^{2}$ pada suhu $121^{\circ} \mathrm{C}$, waktu sterilisasi tergantung pada sifat bahan yang disterilkan, tipe wadah dan volume bahan, biasanya sekitar 15-20 menit (waluyo,2008). Diameter hambatan yang dihasilkan dari ekstrak pekat etanol, fraksi heksan, fraksi metilen klorida, fraksi etil asetat dan fraksi butanol terhadap bakteri Staphylococcus aureus, Escherichia coli, pseudomonas aeruginosa, bacillus subtilis, Shigella dysentri dan Salmonella parathypii sebagai bakteri uji, dapat dilihat pada hasil pengujian aktivitas antibakteri dibawah ini:

Tabel 2. Hasil penapisan Fitokimia Hedyotis Corimbosa (L.) Lamk)

\begin{tabular}{|c|c|c|c|c|c|c|c|}
\hline No & Gol.Senyawa & Eks.Etanol & F.Heks & F.MTC & F.E.asetat & F.BuOH & Residu \\
\hline 1 & Tanin & + & + & + & + & + & + \\
\hline 2 & Fenol & + & + & + & + & + & + \\
\hline 3 & Alkaloid & - & - & - & - & - & - \\
\hline 4 & Terpenoid & + & + & + & + & + & + \\
\hline 5 & Saponin & + & - & - & + & - & - \\
\hline 6 & Flavonoid & + & - & + & + & - & - \\
\hline 7 & Triterpenoid & - & - & - & - & - & - \\
\hline 8 & Steroid & + & + & + & + & + & + \\
\hline
\end{tabular}

Keterangan : $+=$ Terdeteksi

- $=$ Tidak terdeteksi 
Tabel 3. Hasil Uji Aktivitas Antibakteri Dari Masing-masing Fraksi Hasil Pemisahan ekstraksi pada kosentrasi 2,5 $\%$ dalam pelarut

\begin{tabular}{|l|c|c|c|c|c|c|c|c|c|c|}
\hline \multirow{3}{*}{ Bakteri Uji } & \multicolumn{10}{|c|}{ Diameter Hambatan (mm) } \\
\cline { 2 - 13 } & \multicolumn{2}{|c|}{ Etanol } & \multicolumn{2}{c|}{ Heksan } & \multicolumn{2}{c|}{ MTC } & \multicolumn{2}{c|}{ E.asetat } & \multicolumn{2}{c|}{ butanol } \\
\cline { 2 - 13 } & I & II & I & II & I & II & I & II & I & II \\
\hline S. Disentri & 6 & 6 & 15 & 14 & 15 & 14 & 12 & 12 & 6 & 6 \\
\hline S. Parathypii & 12 & 10 & 11 & 11 & 10 & 10 & 12 & 11 & 6 & 6 \\
\hline P.Auroginosa & 6 & 6 & 6 & 6 & 14 & 14 & 6 & 6 & 6 & 6 \\
\hline B. Subtilis & 9 & 9 & 13 & 12 & 16 & 17 & 10 & 11 & 6 & 6 \\
\hline S. Aureus & 6 & 6 & 12 & 11 & 9 & 8 & 6 & 6 & 7 & 7 \\
\hline E. Coli & 6 & 6 & 6 & 6 & 10 & 9 & 6 & 6 & 6 & 6 \\
\hline
\end{tabular}

Tabel 4. Hasil Uji Aktivitas Antibakteri Dari Masing-masing Fraksi Hasil Pemisahan ekstraksi pada kosentrasi $5 \%$ dalam pelarut

\begin{tabular}{|l|c|c|c|c|c|c|c|c|c|c|}
\hline \multirow{3}{*}{ Bakteri Uji } & \multicolumn{9}{|c|}{ Diameter Hambatan (mm) } \\
\cline { 2 - 14 } & \multicolumn{2}{|c|}{ Metanol } & \multicolumn{2}{|c|}{ Heksan } & \multicolumn{2}{c|}{ MTC } & \multicolumn{2}{c|}{ E.asetat } & \multicolumn{2}{c|}{ butanol } \\
\cline { 2 - 14 } & I & II & I & II & I & II & I & II & I & II \\
\hline S. Disentri & 19 & 16 & 18 & 17 & 22 & 23 & 16 & 15 & 6 & 6 \\
\hline S. Parathypii & 9 & 8 & 14 & 13 & 11 & 12 & 11 & 10 & 6 & 6 \\
\hline P.Auroginosa & 6 & 6 & 6 & 6 & 14 & 14 & 6 & 6 & 6 & 6 \\
\hline B. Subtilis & 12 & 12 & 15 & 14 & 13 & 13 & 9 & 10 & 6 & 6 \\
\hline S. Aureus & 6 & 6 & 14 & 15 & 12 & 11 & 7 & 7 & 6 & 6 \\
\hline E. Coli & 6 & 6 & 6 & 6 & 12 & 11 & 6 & 6 & 6 & 6 \\
\hline
\end{tabular}

Tabel 5. Hasil Uji Aktivitas Antibakteri Dari Masing-masing Fraksi Hasil Pemisahan ekstraksi pada kosentrasi 10 $\%$ dalam pelarut

\begin{tabular}{|c|c|c|c|c|c|c|c|c|c|c|}
\hline \multirow{3}{*}{ Bakteri Uji } & \multicolumn{10}{|c|}{ width Hambatan (mm) } \\
\hline & \multicolumn{2}{|c|}{ Metanol } & \multicolumn{2}{|c|}{ Heksan } & \multicolumn{2}{|c|}{ MTC } & \multicolumn{2}{|c|}{ E.asetat } & \multicolumn{2}{|c|}{ butanol } \\
\hline & I & II & I & II & I & II & I & II & $\mathrm{I}$ & II \\
\hline S. Disentri & 22 & 20 & 21 & 21 & 28 & 27 & 21 & 20 & 6 & 6 \\
\hline S. Parathypii & 8 & 8 & 14 & 15 & 16 & 15 & 13 & 11 & 7 & 7 \\
\hline P.Auroginosa & 6 & 6 & 6 & 6 & 14 & 14 & 6 & 6 & 6 & 6 \\
\hline B. Subtilis & 11 & 11 & 14 & 15 & 16 & 17 & 10 & 11 & 6 & 6 \\
\hline S. Aureus & 6 & 6 & 14 & 13 & 18 & 17 & 8 & 8 & 6 & 6 \\
\hline E. Coli & 6 & 6 & 6 & 6 & 14 & 14 & 6 & 6 & 6 & 6 \\
\hline
\end{tabular}

Keterangan : I,II = Diameter hambatan pada cawan 1,2

Diameter lubang adalah $6 \mathrm{~mm}$ 
Dari hasil pengujian aktivitas antibakteri diketahui bahwa fraksi hasil ekstrak etanol dengan berbagai pelarut, memberikan aktivitas antibakteri yang berbeda-beda terhadap bakteri uji, perbedaan aktivitas pada masing-masing fraksi dapat disebabkan perbedaan komponen yang terekstraksi artiya bahwa kandungan senyawa yang bersifat antibakterinya berbedabeda pada tiap-tiap komponen. fraksi metilen klorida adalah fraksi yang mempunyai aktivitas antibakteri yang paling tinggi di antara fraksifraksi yang lain, suatu zat dikatakan aktif atau tidaknya dapat dilihat dari daerah bening yang dihasilkan, semakin banyak zat aktif yang diserap maka daerah bening yang dihasilkan akan lebih besar. Fraksi metilen klorida dengan konsentrasi $10 \%$ dalam pelarut dimetil sufoksida (DMSO) dapat menghambat bakteri Shigella dysentri sebesar $27,5 \mathrm{~mm}$, bakteri Staphylococcus aureus fraksi ini mampu menghambat sebesar $17,5 \mathrm{~mm}$, terhadap bakteri Bacilius subtilis dan Salmonella parathyppi dapat menghambat masing-masing sebesar 16,5 $\mathrm{mm}$ dan $15,5 \mathrm{~mm}$, fraksi metilen klorida hanya menghambat bakteri Pseudomonas aeruginosa dan Escherichia coli sebesar 14 mm, aktivitas ini muncul kadar zat aktif yang bersifat antibakteri dalam fraksi metilen klorida lebih tinggi dibandingkan dengan zat aktif yang terkandung dalam fraksi-fraksi lain, dan bila dilihat dari hasil pengujian fitokimia yang didapat dalam metilen klorida terdeteksi golongan senyawa flavonoid dan diduga segolongan senyawa ini yang memiliki sifat antibakteri paling besar. Sedangkan aktivitas paling kecil terjadi pada fraksi butanol fraksi ini tidak memberikan hambatan pada semua bakteri uji baik pada konsentrasi $2.5 \%, 5 \%$ maupun $10 \%$ karena dalam fraksi butanol kandungan zat aktif antibakteri rendah atau sama sekali tidak mengandung zat antibakteri diameter hambat yang dihasilkan $6 \mathrm{~mm}$ dan ini merupakan diameter lubang.

Oleh karena itu fraksi metilen klorida perlu diteliti lebih lanjut karena fraksi ini yang mempunyai aktivitas antibakteri paling tinggi dengan jumlah rendemen yang banyak dan diharapkan dapat memperoleh senyawa aktif yang cukup banyak pula sehingga mempunyai potensi untuk dikembangkan kearah pencarian antibakteri. Salah satu contoh hasil pengujian aktivitas antibakteri dapat dilihat pada Gambar 1.

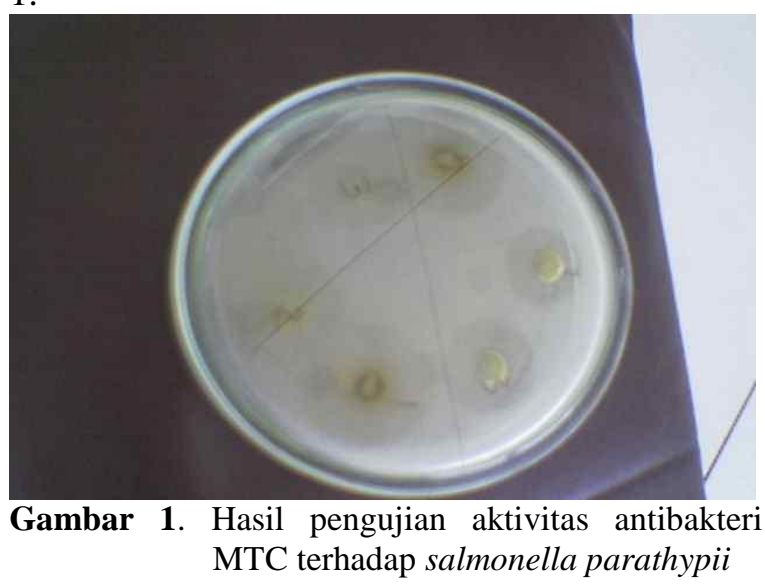

\section{Penentuan Konsentrasi Hambatan Minimum (MIC)}

Fraksi yang miliki aktivitas antibakteri yang paling besar di tentukan Konsentrasi Hambat Minimumnya (KHM) dalam penelitian fraksi yang memiliki diameter paling besar adalah metilen klorida. Daerah hambatan pertumbuhan yang dihasilkan untuk tiap bakteri uji dapat dilihat dalam Tabel 6.

Dari hasil Uji MIC dengan konsentrsi $0.3125,0.6125,1.25,2.5$ dan $5 \%$ dalam pelarut dimetil supoksida (DMDO), fraksi MTC yang dihasilkan dari ekstrak rumput mutiara pada konsentrasi 0.3125 sampai $1.25 \%$ belum dapat menghambat pertumbuhan bakteri yang diuji, hal ini terjadi karena konsentrasi yang digunakan lebih rendah sehingga tidak dapat menghambat pertumbuhan bakteri (Islaha,1999). Pada konsentrasi $2.5 \%$ hanya dapat menghambat pertumbuhan bakteri $S$. Parathypii dan $B$. Subtilis pada sekitar 1875 ppm, sedangkan pada konsentrasi $5 \%$ sudah dapat menghambat pertumbuhan semua bakteri yaitu bakteri S.Aureus, S.Parathypii, P.Auroginosa, E.Coli, S.Subtilis dan S.Disentri disekitar $3750 \mathrm{ppm}$. Dan konsentrasi tersebut merupakan daerah hambatan minimum akan tetapi bukan merupakan KHM sebenarnya, masih merupakan pendekatan karena tidak dilakukan variasi konsentrasi diantara $5 \%$ sampai $2,5 \%$ dan 2.5 sampai $1.25 \%$, dilihat hasil yang diperoleh menunjukkan bahwa semakin kecil konsentrasi fraksi maka semakin sulit untuk menghambat pertumbuhan bakteri karena kadar zat yang bersifat anti aksibakteri yang diserap oleh 
Tabel 6. Hasil Daerah Pertumbuhan Fraksi Metilen Klorida

\begin{tabular}{|c|c|c|c|c|c|c|c|c|c|c|}
\hline \multirow{3}{*}{ Bakteri Uji } & \multicolumn{10}{|c|}{ Hambatan pertumbuhan } \\
\hline & \multicolumn{2}{|c|}{$0.3125 \%$} & \multicolumn{2}{|c|}{$0.6125 \%$} & \multicolumn{2}{|c|}{$1.25 \%$} & \multicolumn{2}{|c|}{$2.5 \%$} & \multicolumn{2}{|c|}{$5 \%$} \\
\hline & I & II & I & II & $\mathrm{I}$ & II & I & II & I & II \\
\hline P.Auroginosa & + & + & + & + & + & + & + & + & - & - \\
\hline S.Parathypii & + & + & + & + & + & + & - & - & - & - \\
\hline S.Disentry & + & + & + & + & + & + & + & + & - & - \\
\hline B.Subtilis & + & + & + & + & + & + & - & - & - & - \\
\hline E.Coli & + & + & + & + & + & + & + & + & - & - \\
\hline S.aureus & + & + & + & + & + & + & + & + & - & - \\
\hline
\end{tabular}

Keterangan $\quad-\quad \quad$ : Menghambat pertumbuhan (Tidak terjadi pertumbuhan bakteri).

$+\quad$ : Tidak menghambat pertumbuhan (Terjadi pertumbuhan).

I,II : Pertumbuhan pada cawan petri ke 1,2

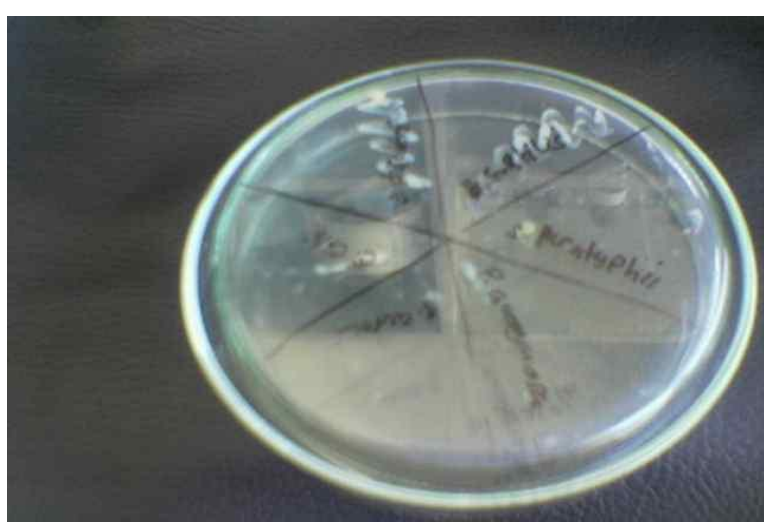

Gambar 2. Hasil pengujian Aktivitas antibakteri MIC Terhadap Faksi Metilen Klorida

bakteri lebih kecil sehingga pendistribusianya tidak merata begitu juga sebaliknya semakin besar konsetrasi maka hambatan pertumbuhan semakin bagus. Salah satu contoh hasil pengujian aktivitas antibakteri MIC dapat dilihat pada Gambar 2.

\section{Pengujian Aktivitas Antibakteri Standar Tetrasiklin Kristal}

Sebagai zat perbanding antara fraksi aktif (ekstrak rumput mutiara) dalam pengujian aktivitas antibakteri maka dilakukan pengujian aktivitas antibakteri terhadap standar tetrasiklin. Diameter hambatan yang dihasilkan dapat dilihat pada Tabel 7.

Salah satu contoh hasil pengujian aktivitas antibakteri standar tetrasiklin dapat dilihat pada Gambar 3.

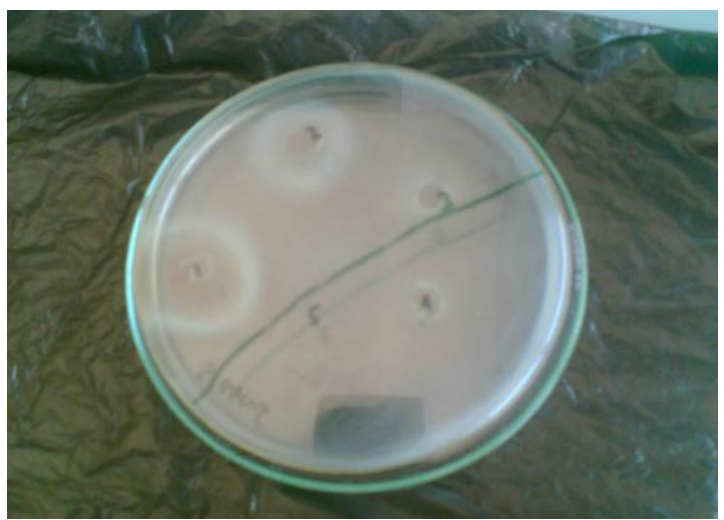

Gambar 3. Hasil pengujian aktivitas antibakteri Standar tetrasiklin

Hasil penelitian menunjukan bahwa tumbuhan rumbut mutiara (Hedyotis Corymbosa (L.) Lamk), memiliki aktivitas antibakteri dalam pelarut metilen klorida hal ini menandakan bahwa senyawa aktif yang bersifat antibakteri pada rumput mutiara dapat larut dalam pelarut semi polar (pelarut metilen klorida) dan sedikit larut dalam pelarut $\mathrm{n}$-haksan (non polar), bahkan tidak larut dalam pelarut polar (butanol). Bila dilihat dari hasil uji fitokimia dibandingkan terhadap aktivitas antibakeri antara butanol dan metilen klorida diduga zat aktif yang bersifat anti bakteri adalah senyawa dari golongan flavonoid. Dari hasil uji konsentrasi hambatan minimum diperoleh data bahwa fraksi metilen klorida pada penelitian ini memiliki MIC pada 5 $\%$ terhadap bakteri pada semua bakteri yaitu P.Auroginoga, S.Aureus, S.Parathypii, 
Tabel 7. Hasil Daerah Diameter Hambatan Standar Tetrasiklin kristalin

\begin{tabular}{|c|c|c|c|c|c|c|c|c|c|c|c|}
\hline \multirow{2}{*}{ NO } & \multirow{2}{*}{ Bakteri Uji } & \multicolumn{10}{|c|}{ Diameter Hambatan $(\mathrm{mm})$} \\
\cline { 3 - 15 } & & $0.3125 \%$ & $0.6125 \%$ & \multicolumn{2}{|c|}{$1,25 \%$} & \multicolumn{2}{|c|}{$2.5 \%$} & \multicolumn{2}{|c|}{$5 \%$} \\
\cline { 3 - 15 } & I & II & I & II & I & II & I & II & I & II \\
\hline 1 & S.Parathypii & 23 & 23 & 32 & 32 & 35 & 34 & 32 & 30 & 36 & 35 \\
\hline 2 & P.Auroginosa & 22 & 23 & 21 & 22 & 21 & 22 & 23 & 23 & 25 & 27 \\
\hline 3 & E. Coli & 21 & 21 & 21 & 23 & 26 & 27 & 30 & 28 & 22 & 23 \\
\hline 4 & S.Aureus & 27 & 26 & 31 & 32 & 35 & 33 & 38 & 40 & 40 & 45 \\
\hline 5 & S. Disentry & 6 & 6 & 6 & 6 & 6 & 6 & 6 & 6 & 6 & 6 \\
\hline 6 & B. Subtilis & 32 & 30 & 36 & 34 & 36 & 36 & 36 & 35 & 35 & 37 \\
\hline
\end{tabular}

Keterangan :

I,II : Diameter pada cawan ke-1, 2

: Diameter lubang adalah $6 \mathrm{~mm}$

B.Subtilis, E.Coli dan S.Disentri serta $2.5 \%$ terhadap bakteri S.Paratypii dan B.Subtilis. Hasil pengujian aktivitas antibakteri terhadap fraksi metilen klorida jika dibandingkan dengan hasil pengujian aktivitas antibakteri terhadap standar tetrasiklin menunjukkan bahwa fraksi MTC lebih baik dibandingkan dengan standar tetrasiklin terhadap bakteri S.Disentri, sementara standar tetrasiklin lebih baik dibanding dengan fraksi MTC terhadap S.Aureus dengan konsentrasi yang sama yaitu pada $5 \%$.

\section{KESIMPULAN DAN SARAN}

\section{Kesimpulan}

Dari hasil penelitian yang dilakukakan maka kesimpulan yang dapat diambil sebagai berikut :

1. Dalam ekstrak rumput mutiara terdapat suatu zat aktif yang berfungsi sebagai antibakteri yaitu yang terdapat dalam fraksi metilen klorida.

2. Pada fraksi metilen klorida aktivitas antibakteri paling baik yaitu pada bakteri S.Disentry dengan Diameter Daerah Hambat sebesar $27.5 \mathrm{~mm}$.

\section{Saran}

Untuk mengungkap lebih jauh mengenai potensi ekstrak rumput mutara (Hedyotis corimbosa (L.) Lamk) yang digunakan dalam penelitian ini perlu dilakukan penelitian lebih

lanjut dengan menggunakan pelarut lain, media lain dan metode yang berbeda dan dilakukan

pengisolasian untuk mengetahui jenis dan karakteristik senyawa yang bersifat antibakteri.

\section{DAFTAR PUSTAKA}

1. Andrea yan. 2000. Aktivitas Antimikroba Dari Ekstrak Dan Fraksinasi Ekstrak tumbuhan Daun Sendok. Laporan Kerja Lapang (PKL). Fakultas MIPA, ITB.

2. Anonim. 1983. Pemanfaatan Tanaman Obat. Kedisi III, 40, Departemen Kesehatan Republik Indoensia, Jakarta.

3. Harborne, J.R. 1987. Metode fitokimia Pantunan Cara Metode Menganalisis Tumbuhan. ITB, Bandung.

4. Irianto, K. 2006. Mikrobiologi Menguak Dunia mikroorganisme Jilid 1, CVY rama Widya. Bandung.

5. Islaha.I,1999. Aktivitas Antibakteri Ekstrak Daun Ceguk. Skripsi. Fakultas MIPA. UNPAD. Jatinangor.

6. Jawetz, dkk, 2001. Mikrobiologi Kedokteran. Salemba medika. Jakarta.

7. Trevor Robinson, 1995. Kandungan Organik Tumbuhan Tinggi. ITB, Bandung.

8. Waluyo Lud, 2008. Teknik Dan Metode Dasar Dalam Mikrobiologi. Universitas Muhammadyah malang, Malang.

9. Yazid Estien, 2005. Kimia Fisika Untuk Paramedis. Andi jogyakata. 